\section{The Need for a New Narrative}

\author{
Ottomar Bahrs ${ }^{1,2 *}$ \\ ${ }^{1}$ Institute of General Practice, University of Duesseldorf, Germany
}

${ }^{2}$ Umbrella Organisation Salutogenesis, Göttingen, Germany

\begin{abstract}
The shock came with the Corona pandemic. The world, as we know it, is dissolving. As the health risk increased, so did the uncertainty about economic and political developments. The political actors "drive on sight", supported by the new lead sciences of virology and epidemiology. This strategy favours a biopolitical shortening of an understanding of health. The extensive closure of public life (lockdown) can be seen as the largest non-medical intervention measure to date.
\end{abstract}

These measures have consequences for citizens' social relations, for their emotional state, for the organization of the social body and the symbolic order. The way the crisis is managed points beyond the pandemic itself and continues development processes that have been ongoing for some time. In particular, the relationship of humans to themselves and nature is under discussion.

There is no agreement on how to assess this social process in the current debate. The question of which interpretative concepts will prevail cannot be thought independently of social power and different needs and interests. The necessity and possibility of a new narrative thus emerge.

Keywords: Corona-Crisis; Narrative; Process of Civilisation; Social Distancing; Social formation of bodies and emotions

The shock came with the Corona pandemic. "The world as we know it is dissolving" [1]. While the infection initially seemed to be limited to the distant city of Wuhan in the Chinese province of Hubei, it soon became clear that the virus knows no borders. As it had before, it could take advantage of the capital flows, the goods and the people, the transport routes created by globalization and spread rapidly. As the health risk increased, so did the uncertainty about economic and political developments. Jürgen Habermas summarised: "We know a lot about what we do not know" [2].

The virus was a blank slate - it was only gradually that knowledge of the pathways of infection and the typical symptoms and course of the disease began to expand. Treatment options were limited so that

${ }^{\star}$ Corresponding author: Ottomar Bahrs, Institute of General Practice, University of Duesseldorf, Germany, Tel: +49 551398195; E-mail: obahrs@gwdg.de

Citation: Bahrs O (2022) The Need for a New Narrative. J Altern Complement Integr Med 8: 224.

Received: February 15, 2022; Accepted: February 16, 2022; Published: February 23, 2022

Copyright: (c) 2022 Bahrs O. This is an open-access article distributed under the terms of the Creative Commons Attribution License, which permits unrestricted use, distribution, and reproduction in any medium, provided the original author and source are credited. symptom relief and behavioural recommendations that had proved effective in connection with other highly infectious diseases were chosen (keeping distance and hygiene, later also everyday masks and increased ventilation). Given the perceived threat, it was understandable that the most extraordinary efforts were devoted to developing a vaccine as quickly as possible.

In the meantime, the political actors had to react. In the knowledge that for the time being, they could only "drive on sight", decisions on crisis management - at least in public presentation - were closely coordinated with "science" and repeatedly "readjusted". On closer examination, it becomes clear that the scientists giving advice are recruited primarily from the new lead sciences of virology and epidemiology. This selection favours a biopolitical shortening of an understanding of health. The extensive closure of public life (lockdown) can be seen as the most considerable non-medical intervention measure to date [3], which, contrary to the presented solidarity with "the sciences", cannot be based on evidence to a large extent. Non-drug measures can have side effects [4]. The British scientist McCartney [5] calls for "We need better evidence on non-drug interventions for covid-19", while her British colleague Trisha Greenhalgh advocates a paradigm shift to make the complex events describable across disciplines [3]. These measures have consequences for the social relations of citizens, for their emotional state, for the organization of the social body and the symbolic order. To put it in other words: the pandemic is embedded in systemic crises and development processes that have been ongoing for some time.

\section{The Reorganization of the Social Space}

"The world to come will appreciate distance again - and precisely because of this will make connectedness more qualitative". Autonomy and dependence, opening and closing, will be re-balanced. The world will be more complex and more stable at the same time. This transformation is largely a blind evolutionary process - because the one fails, the new, viable, prevails. First, we may feel dizzy, but then it proves its inner meaning: "Sustainable is that which connects the paradoxes on a new level" [1].

In his reflections on a world after Corona, formulated in March 2020, the futurologist Mathias Horx stated that what we experience as an incursion into what appears to be a "normal" world expresses longterm developments and announces comprehensively new forms of social interaction and organization. This will be reflected in changes in the prevailing interpretations of reality and lead to a new narrative [1]. Thoughts in the tradition of Norbert Elias' sociology of figuration point in a similar direction, which draw attention to the emerging consequences of social affect structures [6]. Thus, the corona crisis is understood as a comprehensive crisis of change in contemporary society. The character of upheaval is expressed in condensed form in the talk of the "corona times" [7]. So what is going on there?

In the early phase of the lockdown, there was a remarkable awareness of the restructuring of the social space and the consequences for social relations of the imperative to keep one's distance and stay at home. Because of the social isolation associated with the lockdown, 
Phil Langer recalls the figure of "homo clausus" described by Elias as a result of the internalization of foreign constraints into self constraints in the process of civilization [8]. Could what appears epidemiologically necessary in the acute situation have consequences for the design of future social interactions beyond the end of the pandemic and be permanently reflected in people's psychological and affective structure?

"Do the behavioral regulations introduced in the existentially perceived crisis as a direct response and intervention change in the long term the way we encounter each other without the need for legal regulations and the threat of punishment, and the way we perceive, think, feel [6]"?

The change in the rules for regulating distance is apparent in gestures (elbow strike instead of shaking hands) and facial expressions (mask instead of expression) and is also symbolically effective. "Handshakes symbolize the internalization of both humanist-egalitarian bonds between people and the collective-nationalist ties between states [7]. Paradoxically, the mutual elbow strike presupposes a reduction of the distance. In the opposite direction, the sign of mutual consideration transports the existing potential for aggression more strongly than the handshake. Similarly, the mask covers the expression and stimulates parallel fantasies about what is covered. The realization, therefore, requires a special tolerance of ambiguity.

"How is that possible: Man, who is a social being, should avoid the social which suddenly poses existential risks for him. People with gloves, with mouthguards, worried looks, anxious movements" [8].

As the behaviour of individuals changes, their relationship to each other also changes. According to Elias, societies can be described as figurations of bodies that move according to rules. It should be emphasized that the bodies are to be understood simultaneously as biological beings and as communication media. "It is precisely this dual character that viruses make use of. In order to fight them, the social function of the body is now being extremely reduced" [9]. In other words: the rules of movement are being changed, spaces of experience and encounter are being limited. This increases the risk of social detachment, irrespective of infection. Division processes are the result, and the foundation of pluralistic democracy, taken for granted in everyday social interaction, is shaky. Society is a physical - often mute - process [9].

These changes, which structure everyday life, are accompanied by uncertainty, and the rules that are becoming established are repeatedly violated even by political leaders [10]. According to the Australian sociologist Robert van Krieken, this process of change, which will become apparent with Covid-19, must be understood in the context of already existing social structures, dynamics and processes, some of which are accelerated or particularly accentuated by the pandemic. In particular, the relationship of humans to themselves and nature is under discussion.

From Elias's perspective, the measures that public health experts have advocated since the 1970s, both short- and long-term, 'stand for' or 'represent' a more generalized capacity for self-restraint. This shaping of habitus has more to do with the structure and dynamics of social relations more broadly - particularly our relation to the non-human world - than the 'solution' to a specific public health problem [11].
There is no agreement on how to assess this social process in the current debate. While Horx sees the virus as an evolutionary accelerator and raises the question of whether "the virus has changed our lives in a direction that it wanted to change anyway" [1]? others fear a rise in biased social control or even a kind of hygiene dictatorship $[12,13]$. While Horx, given the spreading crisis, hoped that it would lead to the creation of a new, meaningful narrative [1], Phil Langer simultaneously stated that no orientation in the flood of information is possible at present, as a shared narrative is missing [8]. The question of which interpretative concepts will prevail cannot be thought independently of social power and different needs and interests [14]. Knoblauch interprets the corona crisis as a conflict between two spatial configurations: the container solution of closed spaces - currently typically favoured by territorial governments and experts, which tends to be associated with a widespread loss of publicity - and the more bottom-up developed network structures.

"Territorial spaces follow the logic of setting and ordering, characterized by drawn boundaries (outwards) and restrictions on diversity (inwards). In contrast, network spaces follow the logic of rationalizing the heterogeneous. In network spaces, distant elements are put into relation, and differences between the elements are the essential characteristics [15]".

\section{Own and Foreign}

The virus is foreign to us - we cannot even tell whether it is "life" or not [16]. However, it can infiltrate us - and this possible crossing of borders ties in with archaic fears [17]. This alien seems dangerous, it can cause serious illness, and because the virus is highly infectious, possible carriers also become a danger. Thus there are good reasons to be afraid of the "other", and at first, this seemed to be people (and animals) from the foreign country. Nevertheless, the border closures did not protect, and the virus is spreading in this country, first in "hotspots" and now nationwide. As a result, everyone can become a dangerous other - a basic situation that fosters mistrust and promotes "othering" [18]. The cultural scientist Insa Härtel points out that parallel to this fear, especially in networked societies, there can also be a desire for infection, a kind of longing for the blurring of boundaries and an almost overpowering desire [19]. Against this background, excesses, such as those observed in demonstrations directed against government policy, can become understandable - and it is possible to guess why attempts to influence behavior through "reasonable" argumentation fail here. Klaus Theweleit had already described this figure in detail as a maintenance mechanism in his analyses of fascism [17]. The fear of the other is not the least since we are unsure of ourselves.

It is worth rethinking here. Reinhold Görling reminds us that humans have always lived in a community with viruses and that this interaction can contribute to better interact with the environment. He concludes:

"The Covid-19 virus is not outside. Something else inside us is not good for us but cannot simply confront. We have to change ourselves, our social behaviour, our conscious thinking, but also the knowledge of our body" [16].

Sabine Hark adds a socio-critical dimension to the argument and writes that the proper host of the parasite is social inequality. Solidarity must therefore be redefined:

"Instead of starting from independently conceived organisms, which reciprocally only represent environment for each other and 
against which we can immunize ourselves in each case, it makes sense to learn to think from an always already interwoven, emergent event. We must learn to live with the virus instead of acting against it. As paradoxical as it may sound: we live in a community with the virus, we must form communities with it" [20].

The necessity and possibility of a new narrative thus emerge.

\section{What can the Corona Crisis have been good for?}

In an interim review [21], Horx writes that the ideas he formulated at the start of the lockdown about what the corona crisis might have been good for once should have given hope. He wanted to open the space for possible new developments, starting from thinking of a desirable future. Metaphorically speaking:

"Maybe the virus was just a messenger from the future. Its drastic message is that human civilization has become too dense, fast, and overheated. It is racing too fast in a particular direction where there is no future" [1].

In other words, we are currently faced with creating more and more shelters from encroaching social demands to preserve our biological basis - our own and the environment that feeds us. To this extent, renegotiating the relationship between proximity and distance is on the agenda. However, this is not in the pursuit of social control but instead of strengthening autonomy and participation. It is oriented towards a homo integrus and inseparably linked to reducing the social distance within and between societies.

"Such meta-civilizing processes will only be organized around rational reflection to a limited extent. In significant ways, they will be constituted by shifts at the emotional and psychological level, in the realm of culture and habitus, by the formation of particular ways of being a person, and any changes at the level of social institutions and forms will remain relatively insignificant in the absence of changes at that level as well" [11].

\section{References}

1. Horx M (2020) Die Welt nach Corona: Die Corona-Rückwärts-Prognose: Wie wir uns wundern werden, wenn die Krise ,vorbei” ist. Matthew Horx, Germany.

2. Schering M (2020) Habermas spricht über Corona: „So viel Wissen über unser Nichtwissen gab es noch nie“, Germany.

3. Greenhalgh T (2020) Will COVID-19 be evidence-based medicine's nemesis? PLoS Med 17: 1003266.
4. Gäbel G, Kröger K (2020) Risiken der „Stay at home“-Politik im Rahmen der COVID-19-Pandemie. Gefässchirurgie 25: 403-407.

5. McCartney M (2020) We need better evidence on non-drug interventions for covid-19. BMJ 370: 3473.

6. Langer P (2020) Overkill - Autoethnographische Notizen zur Corona-Pandemie Teil 4: Abstand. International Psychoanalytic University, Germany.

7. Mack A (2020b) Short Process Reflections on the Pandemic 2. Norbert Elias Foundation, The Netherlands.

8. Langer P (2020b): Overkill - Autoethnographische Notizen zur Corona-Pandemie Teil 2: Angst? International Psychoanalytic University, Germany.

9. Randow G (2020) Demokratie in Zeiten des Coronavirus: Die biopolitische Krise; Die ZEIT. ZEIT ONLINE, Germany.

10. Fellmer JP (2020) Vorbilder auf Abwegen - Wenn Politiker Corona-Regeln brechen. Weser Kurier, Germany.

11. Krieken RV (2020) Covid-19 and the Civilizing Process. Journal of Sociology 56: 714-725.

12. Kehr J (2020) Sich der Pandemie hingeben. Schreiben und Nervosität in Zeiten von Covid-19 (\#WitnessingCorona). Working Group Medical Anthropology, Germany.

13. Monaghan LF (2020) Coronavirus (COVID-19), pandemic psychology and the fractured society: a sociological case for critique, foresight and action. Sociology of Health \& Illness 42: 1-14.

14. Mack A (2020) Short Process Reflections on the Pandemic 1. Norbert Elias Foundation, The Netherlands.

15. Knoblauch H (2020) Symbole und Räume - Soziologische Reflexionen aus dem Inneren der Corona-Krise. Re-Figration von Roumen, Germany.

16. Görling R (2020) Corona und die Scham. International Psychoanalytic University Berlin, Germany.

17. Theweleit K (1977) Männerphantasien 2 Bände, Verlag Roter Stern/Stroemfeld, Frankfurt/M. u. Basel. Germany.

18. Ward P (2020) A sociology of the Covid-19 pandemic: A commentary and research agendafor sociologists. Journal of Sociology 56: 726-735.

19. Härtel I (2020) Phantasmatische Aspekte der Covid-19-Pandemie. International Psychoanalytic University Berlin, Germany.

20. Hark S (2020) Die Netzwerke des Lebens. Germany.

21. Horx M (2020) Die Wahrheit nach Corona - Zwischenbilanz einer Krise. Matthew Horx, Germany. 


\section{H}

Advances In Industrial Biotechnology | ISSN: 2639-5665

Advances In Microbiology Research | ISSN: 2689-694X

Archives Of Surgery And Surgical Education | ISSN: 2689-3126

Archives Of Urology

Archives Of Zoological Studies | ISSN: 2640-7779

Current Trends Medical And Biological Engineering

International Journal Of Case Reports And Therapeutic Studies | ISSN: 2689-310X

Journal Of Addiction \& Addictive Disorders | ISSN: 2578-7276

Journal Of Agronomy \& Agricultural Science | ISSN: 2689-8292

Journal Of AIDS Clinical Research \& STDs | ISSN: 2572-7370

Journal Of Alcoholism Drug Abuse \& Substance Dependence | ISSN: 2572-9594

Journal Of Allergy Disorders \& Therapy | ISSN: 2470-749X

Journal Of Alternative Complementary \& Integrative Medicine | ISSN: 2470-7562

Journal Of Alzheimers \& Neurodegenerative Diseases | ISSN: 2572-9608

Journal Of Anesthesia \& Clinical Care | ISSN: 2378-8879

Journal Of Angiology \& Vascular Surgery | ISSN: 2572-7397

Journal Of Animal Research \& Veterinary Science | ISSN: 2639-375

Journal Of Aquaculture \& Fisheries | ISSN: 2576-5523

Journal Of Atmospheric \& Earth Sciences | ISSN: 2689-8780

Journal Of Biotech Research \& Biochemistry

Journal Of Brain \& Neuroscience Research

Journal Of Cancer Biology \& Treatment | ISSN: 2470-7546

Journal Of Cardiology Study \& Research | ISSN: 2640-768X

Journal Of Cell Biology \& Cell Metabolism | ISSN: 2381-1943

Journal Of Clinical Dermatology \& Therapy | ISSN: 2378-8771

Journal Of Clinical Immunology \& Immunotherapy | ISSN: 2378-8844

Journal Of Clinical Studies \& Medical Case Reports | ISSN: 2378-880

Journal Of Community Medicine \& Public Health Care | ISSN: 2381-1978

Journal Of Cytology \& Tissue Biology | ISSN: 2378-9107

Journal Of Dairy Research \& Technology | ISSN: 2688-9315

Journal Of Dentistry Oral Health \& Cosmesis | ISSN: 2473-6783

Journal Of Diabetes \& Metabolic Disorders | ISSN: 2381-201X

Journal Of Emergency Medicine Trauma \& Surgical Care | ISSN: 2378-8798

Journal Of Environmental Science Current Research | ISSN: 2643-5020

Journal Of Food Science \& Nutrition | ISSN: 2470-1076

Journal Of Forensic Legal \& Investigative Sciences | ISSN: 2473-733X

Journal Of Gastroenterology \& Hepatology Research | ISSN: 2574-2566
Journal Of Genetics \& Genomic Sciences | ISSN: 2574-2485

Journal Of Gerontology \& Geriatric Medicine | ISSN: 2381-8662

Journal Of Hematology Blood Transfusion \& Disorders | ISSN: 2572-2999

Journal Of Hospice \& Palliative Medical Care

Journal Of Human Endocrinology | ISSN: 2572-9640

Journal Of Infectious \& Non Infectious Diseases | ISSN: 2381-8654

Journal Of Internal Medicine \& Primary Healthcare | ISSN: 2574-2493

Journal Of Light \& Laser Current Trends

Journal Of Medicine Study \& Research | ISSN: 2639-5657

Journal Of Modern Chemical Sciences

Journal Of Nanotechnology Nanomedicine \& Nanobiotechnology | ISSN: 2381-2044

Journal Of Neonatology \& Clinical Pediatrics | ISSN: 2378-878X

Journal Of Nephrology \& Renal Therapy | ISSN: 2473-7313

Journal Of Non Invasive Vascular Investigation | ISSN: 2572-7400

Journal Of Nuclear Medicine Radiology \& Radiation Therapy | ISSN: 2572-7419

Journal Of Obesity \& Weight Loss | ISSN: 2473-7372

Journal Of Ophthalmology \& Clinical Research | ISSN: 2378-8887

Journal Of Orthopedic Research \& Physiotherapy | ISSN: 2381-2052

Journal Of Otolaryngology Head \& Neck Surgery | ISSN: 2573-010X

Journal Of Pathology Clinical \& Medical Research

Journal Of Pharmacology Pharmaceutics \& Pharmacovigilance | ISSN: 2639-5649

Journal Of Physical Medicine Rehabilitation \& Disabilities | ISSN: 2381-8670

Journal Of Plant Science Current Research | ISSN: 2639-3743

Journal Of Practical \& Professional Nursing | ISSN: 2639-568

Journal Of Protein Research \& Bioinformatics

Journal Of Psychiatry Depression \& Anxiety | ISSN: 2573-0150

Journal Of Pulmonary Medicine \& Respiratory Research | ISSN: 2573-0177

Journal Of Reproductive Medicine Gynaecology \& Obstetrics | ISSN: 2574-2574

Journal Of Stem Cells Research Development \& Therapy | ISSN: 2381-2060

Journal Of Surgery Current Trends \& Innovations | ISSN: 2578-7284

Journal Of Toxicology Current Research | ISSN: 2639-3735

Journal Of Translational Science And Research

Journal Of Vaccines Research \& Vaccination | ISSN: 2573-0193

Journal Of Virology \& Antivirals

Sports Medicine And Injury Care Journal | ISSN: 2689-8829

Trends In Anatomy \& Physiology | ISSN: 2640-7752

Submit Your Manuscript: https://www.heraldopenaccess.us/submit-manuscript 